\section{Ordforklaringer}

Schizofreni: Regnes som den mest alvorlige psykotiske lidelsen, ikke minst fordi den rammer mennesker i yngre alder og invalidiserer en større del av pasientene, spesielt i sosialt henseende (1)

\section{Litteratur}

1. Malt UF, Retterstøl N, Dahl AA. Lærebok i psykiatri. 2. utg. Oslo: Gyldendal Akademisk, 2003

Ultralydangiografi: Ultralydteknikk som viser blodgjennomstrømning og lokalisasjon av blodårer. Synonym: power doppler.

Se oversikt over doktoravhandlinger i seksjonen Oss imellom på side 82

\title{
Forandringer i hjernen hos schizofrene
}

\author{
Pasienter med schizofreni har tynnere hjernebark og mindre volum \\ av hjernevev i panne- og tinninglappene enn friske. Endringene \\ er sykdomsrelatert.
}

Schizofreni rammer om lag $1 \%$ av befolkningen. Sykdommen debuterer oftest i begynnelsen av 20-årene, og menn er yngre enn kvinner ved debut. Antipsykotiske medikamenter kan lindre symptomer, men de fleste pasientene trenger langvarig behandling. I avhandlingen Characterization of brain morphology in patients with schizophrenia påviser Ragnar Nesvåg endringer i hjernemorfologi hos pasienter med

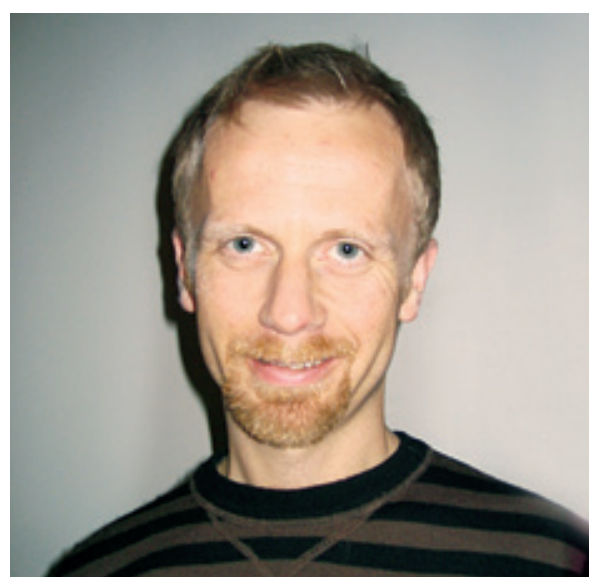

Ragnar Nesvåg. Foto Ida Rambæk schizofreni. Resultatene bygger på klinisk intervju og MR-undersøkelser av pasienter og kontrollpersoner.

- Vi har sett på om alder, kjønn, bruk av antipsykotiske medikamenter og alkohol samt type og grad av symptomer har betydning for tykkelse av hjernebarken og volum av hjernevev. Vi fant forskjeller i hjernemorfologi hos mannlige og kvinnelige pasienter, men dette forklarer ikke hvorfor menn får sykdommen tidligere, har dårligere effekt av medisinering og dårligere prognose, sier Nesvåg.

Alkoholkonsum kan relateres til mindre volum av hvit hjernemasse i hele hjernen og i tinninglappen, men forklarer ikke forskjell i hjernevolum hos friske og syke. Alder og bruk av medikamenter var uten betydning.

- Det er klare holdepunkt for at endringer i hjernen hos pasienter med schizofreni skyldes sykdommen. Mer kunnskap om dette kan gi mer effektiv behandling, sier han.

Nesvåg disputerte for ph.d.-graden ved Universitetet i Oslo 14.11. 2008.

Anne Forus

anneforu@online.no

Tidsskriftet

\section{Ultralyd forbedrer nevrokirurgien}

\author{
Nevronavigasjon med tredimensjonal ultralyd kan gi økt sikkerhet \\ og bedre resultater ved nevrokirurgiske operasjoner.
}

Nevronavigasjon betyr å navigere ved hjelp av bildedata under nevrokirurgiske operasjoner. Posisjonen til et kirurgisk instrument vises på MR- eller ultralydbilder under operasjonen. Systemet som ble brukt i doktoravhandlingen til Ola Rygh viser tredimensjonale (3D) ultralydbilder tatt underveis i operasjonen.

- Nevronavigasjon med 3D ultralyd for å vise blodkar (3D ultralydangiografi) er brukt ved operasjon av 62 pasienter med ulike typer hjernesvulster. Det var gode resultater der viktige blodkar lå nært inntil svulsten. Vi tror at navigasjon basert på 3D ultralyd kan gjøre denne typen inngrep sikrere, sier Rygh.

Erfaringer fra inngrep på 19 pasienter med glioblastom viser at 3D ultralyd er svært nøyaktig for å avbilde grensene til svulsten før den fjernes. Ultralydfunn ble sammenliknet med biopsifunn.
Under og etter fjerningen av svulsten var 3D ultralyd noe mindre nøyaktig til å avbilde svulstens grenser. Likevel er 3D ultralyd viktig i alle faser av operasjonen, og under reseksjonen ble ikke tumorrester oversett.

Nevronavigasjon med 3D ultralyd er også brukt ved operasjoner på svulster i ryggmargen og ved hjerneoperasjoner med kikkhullskirurgi.

Ryghs avhandling 3D ultrasoundbased neuronavigation in neurosurgery. A clinical evaluation inngår i ph.d.graden i medisinsk teknologi ved Norges teknisk-naturvitenskapelige universitet. Han disputerte 4.12. 2008.

\section{Anne Forus}

anneforu@online.no

Tidsskriftet 